\title{
Deadweight Loss and the Cost of Public Funds in Australia
}

\author{
Harry Campbell
}

$\mathbf{R}$

ECENT studies of productivity and economic growth have stressed the importance of infrastructure such as transport and education facilities in goods that we share to some extent as opposed to goods that are subject to exclusive private use. According to Otto and Voss (1994), a 10 per cent increase in the public capital stock increases total factor productivity in the private sector by 4 per cent. While infrastructure investment can be undertaken by the private sector, it is generally recognised that some level of government investment is required if the appropriate amounts of public goods are to be provided.

In 1994-95 Australian Commonwealth government outlays totalled $\$ 128$ billion, of which $\$ 97$ billion consisted of transfer payments of various kinds, including interest payments, provision of social security benefits, and grants to the States. The balance was devoted to expenditures on provision of goods and services, including $\$ 6$ billion on goods classified as capital in nature (ABS, 1994/95). The latter sum underestimates the amount of investment undertaken by the Commonwealth, since a proportion of current outlays on areas such as education and health contributes to augmenting the stock of human capital. General government outlays in Australia constituted 37 per cent of Gross Domestic Product as compared with the OECD average of 41 per cent (OECD, 1996: Annex Table 28).

In deciding which goods and services to provide, governments have to take account of the benefits and costs generated by each type of expenditure. Public expenditure can be funded either by taxation or by borrowing, but in the latter case tax revenues are required to meet interest on, and repayment of, loans. Ultimately, the cost of public projects is represented by the costs imposed by raising tax revenues. These costs comprise mainly collection costs, compliance costs and deadweight loss. Collection costs are incurred by the private and public sectors in the battle over the amount of tax due; compliance costs arise from account-keeping and form-filling; and deadweight loss reflects changes in economic behaviour induced by the structure of the tax system (Diewert \& Lawrence, 1995:28). Arguably, while collection and compliance costs may be substantial, they do not increase significantly with an increase in tax rates, whereas the size of the deadweight loss does.

This note is concerned with the deadweight loss associated with raising an additional amount of tax revenue to fund an additional public project in Australia.

Harry Campbell is Professor of Applied Economics at the University of Queensland. 


\section{Notes and Topics}

The cost of the project would be funded by the revenues raised as a result of the tax increase. However, raising this amount of tax revenue imposes an additional cost on the economy in the form of a deadweight loss. This means that the overall cost of the tax increase, and hence the overall cost of the proposed project to the economy, is higher than the revenue raised to fund the project.

The overall cost to the economy of the tax increase expressed as a ratio of the additional tax revenues available to fund a public project is known as the marginal cost of public funds. If we ignore additional compliance and collection costs, the benefits of the proposed project per dollar of cost would need to be at least as large as the marginal cost of public funds to make the project worthwhile. This means that the project would have to provide a return sufficient to cover both a normal rate of return on the funds employed and the marginal deadweight loss.

Campbell and Bond (1997) find that the deadweight loss associated with raising additional tax revenue is 19 per cent, implying that the marginal cost of public funds is around 1.2. This figure is similar to the estimated deadweight loss of 18 per cent that Diewert and Lawrence (1995) find for New Zealand and is within a fairly wide range of estimates that Freebairn (1995) finds for Australia. But while the results of these two studies are not inconsistent with those obtained by Campbell and Bond, the methods of analysis differ. A more direct comparison is provided by Findlay and Jones (1982), who, using a similar approach to that of Campbell and Bond, estimate that the marginal deadweight loss associated with raising and spending tax revenues in Australia lies within the range $23-65$ per cent. The difference between the two findings may be partly attributable to changes in the tax system since 1978-79, and particularly to the lowering of marginal tax rates in high income-tax brackets. However, it is interesting to note that whereas deadweight loss appears to have fallen in Australia, Diewert and Lawrence find an increase in deadweight loss in New Zealand over the period 1972-91. They attribute much of the increase to the greater flexibility of the New Zealand economy, which offers taxpayers more opportunity for changing behaviour in response to tax changes.

\section{The Nature of Deadweight Loss}

Deadweight loss is the cost of changes in incentives to work or invest caused by changes in the level or structure of taxes. Measuring the effects of tax changes on capital flows is very difficult; and most analysis to date has concentrated on the effects of a tax increase on work incentives.

An increase in the tax rate lowers the after-tax wage (the cost of leisure) and makes additional leisure relatively more attractive. However, the lower after-tax wage also reduces disposable income and makes additional leisure less affordable. While these two effects work in opposite directions, it is likely that a reduction in the after-tax wage will increase the amount of leisure, thereby reducing the amount of labour supplied.

To understand the importance of the labour supply response in determining the amount of deadweight loss resulting from an increase in the tax on earnings, consider first the case in which the level of labour supply is unaffected by the tax increase. If the supply of labour remains constant, the value of goods and services produced by 
the economy remauns constant. What happens is that economic activity is redistributed between the private and the public sectors. Since take-home pay falls by the amount of the increase in tax revenues, households reduce their demand for goods and services; this reduction in demand is matched by the government's increased demand for the goods and services required to undertake the additional public project. Since the cost to the household sector is exactly offset by the market value of the additional public project, no net or 'deadweight' loss is imposed on the economy. Of course, this leaves aside the question of whether the value of the output of the public project is sufficient to compensate the household sector for its loss. This is a separate issue, and is considered in the cost-benefit analysis of the proposed project.

Now consider the case in which the quantity of labour supplied falls as a result of the tax increase. The resulting decline in the value of goods and services produced by the economy is measured by the value of the fall in before-tax earnings. However, this decline is partly offset by the value households place on the additional leisure they have chosen to enjoy. Since additional leisure is valued at the after-tax wage, there is a net loss to the economy consisting of the difference between the before-tax and the after-tax value of the reduction in labour supply. This net loss to the economy is termed a deadweight loss.

The cost of the deadweight loss resulting from the reduction in the quantity of labour supplied falls on both government and households. The government loses the tax revenues which would have been paid on the labour which is no longer supplied; and households lose the after-tax income which that labour would have earned (though this is partially offset by the value placed on the extra leisure time which is enjoyed). In addition to the loss resulting from the reduction in labour supply, the household sector also suffers a loss in the form of increased taxes payable on the new level of labour supply.

\section{Estimating Deadweight Loss}

The aim of undertaking an additional public project is to make the household sector better off. This is accomplished if the value of the benefits of the project exceeds the cost imposed on households by the tax increase. However, we have seen that the cost imposed on households exceeds the additional revenue available to fund the project. This means that the nominal cost of the project - the cost of the goods and services purchased by the additional tax revenues and used to construct and operate the project - is less than the cost imposed on households. This in turn implies that the value of the project's benefits has to exceed the nominal cost of the project if

\footnotetext{
${ }^{1}$ The marginal cost of public funds, which reflects the amount of deadweight loss imposed on the economy by the tax increase, can be expressed in two equivalent ways: as the ratio of the cost imposed on households by the tax increase to the extra amount of tax revenue available to fund the public project; and as one plus the ratio of the deadweight loss to the additional amount of tax revenue collected by the government. These two ways of calculating the marginal cost of public funds are equivalent because the extra tax revenues collected plus the deadweight loss equals the cost of the tax increase to the household sector.
} 
households are to be made better off. In fact, the ratio of the value of the project's benefits to nominal cost has to be at least as high as the cost of public funds. This is why the concept of the cost of public funds is so important in the evaluation of public projects.

Information about labour supply and tax rates makes it possible to estimate the cost of public funds. Campbell and Bond (1997) have estimated effective rates of tax for workers in the average household in each of the household gross-income deciles in Australia in the 1988-89 tax year. The effective marginal tax rates (EMTRs) on labour income are 20 per cent in the lowest decile, rising to 67 per cent in the fourth decile and then falling to 44 per cent in the tenth decile. The average EMTR is 47 per cent. These rates may seem surprisingly high, but they incorporate both direct and indirect taxes and include the effects of benefit programs as well as taxation: the EMTR is the increase in tax paid minus benefit received when household income rises by a dollar. In effect, the household is penalised twice when income rises as a result of additional work: it pays more tax and it experiences a reduction in those government benefits which are related to income level.

The EMTR can be expressed as the marginal tax rate (MTR) minus the marginal benefit rate (MBR). The MBR is negative, since benefits received tend to fall as household income rises. A rise in the MTR, involving some mix of direct and indirect taxes, raises the EMTR, thereby tending to cause a decline in household labour supply. Campbell and Bond (1997) assume that additional public funds are obtained by raising the MTR for the average household in each gross income decile by 1 per cent of its original value. Since the MBR is unaffected, this results in nonproportional increases in EMTRs across households.

A rise in the tax rate in order to fund an additional public project causes a decline in the quantity of labour supplied, thereby reducing before-tax incomes and making some households eligible to receive increased benefit levels. How should these increased benefits be financed? It can be argued that the additional tax revenues should be sufficient to fund the additional public project and to pay any additional benefits required under current welfare programs because of the tax increase. In the analysis by Campbell and Bond (1997), this requirement is imposed on the funding of an additional public project.

The size of the reduction in labour supply depends upon the responsiveness of the labour supply to a change in the after-tax wage. Campbell and Bond use estimates for the Australian labour market which indicate that, while households in different income deciles would respond differently to a tax increase, the average household would reduce labour supply by 6 per cent in response to a 10 per cent fall in its aftertax wage. Using a simple model of labour supply incorporating this assumption, they calculate the fall in the amount of labour supplied by the average household in each income decile as a result of a 1 per cent increase in its MTR. Aggregate deadweight loss and aggregate additional tax revenues are calculated by summing across households, and their ratio is used to calculate the deadweight loss per dollar of additional tax revenue available to fund additional public expenditure. A value of 
$\$ 0.19$ is obtained, implying that the cost of public funds is $\$ 1.19$ per dollar of tax revenue.

\section{The Effect of Public Good Provision on Labour Supply}

The labour supply may be affected, not only by the tax increase, but also by the public project itself. For example, a new road could decrease labour supply by making it easier to get to the beach, or increase it by making it easier to get to work. Furthermore, having access to an additional quantity of a public good increases households' economic well-being, thereby making leisure seem more affordable (this sort of reaction is termed an 'income effect'). The net effect of the output of the public project will vary from case to case, but will probably tend to be in the direction of reduced labour supply, thus causing a further reduction in tax revenues.

Little empirical work has been undertaken on the effects of public good provision on labour supply. However, when the value of a public project's benefits is of a similar dimension to its costs (including the deadweight loss), it may be reasonable to assume that the income effects of the public expenditure are roughly equal, although opposite in direction, to the income effects of the tax increase. This assumption can be incorporated in the analysis of the marginal cost of public funds by eliminating the income effect of the tax increase from the calculation. Since the income effect of the tax increase tends to work in the direction of a higher supply of labour, removing it from the calculation tends to raise the marginal cost of public funds.

Campbell and Bond (1997) find that leaving out the income effect of the tax change increases the estimate of deadweight loss by 5 per cent, bringing the estimate of the marginal cost of public funds up to $\$ 1.24$ per dollar of additional tax revenue to be used to fund an additional public project. This value is directly comparable with Findlay and Jones's (1982) results, since it incorporates both the revenue and the expenditure effects of the tax increase. However, the EMTRs that Campbell and Bond estimate for higher-income households in the late 1980s are significantly lower than those estimated by Findlay and Jones for the late 1970s, and this results in a lower estimate of deadweight loss.

\section{Conclusion}

Unless it has particularly desirable income distributional effects, an additional Commonwealth government project should have a benefit/nominal cost ratio of at least 1.24 before being undertaken. The benefits and costs of the project should be measured in the usual way, except that the benefit measure should be adjusted to add (subtract) the value of any increase (decrease) in tax revenues generated as a result of the nature of the project's output as a substitute for (complement to) leisure. This change in tax revenues should be valued at the marginal cost of public funds. In practice, little is known about the substitution or complementarity effects of public expenditure on labour supply; and it will be difficult to account for them in public project evaluation. Where these effects are localised, they may be insignificant in comparison with the overall cost of the project. 


\section{References}

Australian Bureau of Statistics (ABS) (1994/95), Government Finanoe Statistics Australia, Canberra (Cat No. 5512.0).

Campbell, H. \& K. Bond (1997), The Cost of Public Funds in Australia', Economic Record 73: 28-40.

Diewert, W. \& D. Lawrence (1995), 'The Excess Burden of Taxation in New Zealand', Agenda 2(1): 27. 34.

Findlay, C. \& R. Jones (1982), 'The Marginal Cost of Australian Income Taxation', Economic Record 58: 25362.

Freebairn, J. (1995), 'Reconsidering the Marginal Welfare Cost of Taxation', Economic Record 71: 12131.

Organisation for Economic Cooperation and Development (OECD) (1996), Economic Outlook 59, Paris (June).

Otto, G. \& G. Voss (1994), 'Public Capital and Private Sector Productivity', Economic Record 70: 121-32.

The author wishes to thank the editor and two anonymous referees for helpful comments. 